\title{
Distinct recognition of $\mathrm{OX}_{1}$ and $\mathrm{OX}_{2}$ receptors by orexin peptides
}

Sylwia Ammoun, Tomas Holmqvist, Ramin Shariatmadari, Hendrica B. Oonk, Michel Detheux, Marc Parmentier, Karl E. O. Åkerman and Jyrki P. Kukkonen

Department of Neuroscience, Physiology, Laboratory of Cell Physiology, Uppsala University, Uppsala, Sweden (S.A., T.H., R.S., K.E.O.Å., J.P.K.); Department of Molecular Recognition, ID-DLO Institute for Animal Science and Health, Lelystad, The Netherlands (H.B.O.);

Euroscreen s.a., Bruxelles, Belgium (M.D.); the Institute of Interdisciplinary Research, Université Libre de Bruxelles, Bruxelles, Belgium (M.P.); and the A. I. Virtanen Institute for Molecular Sciences, University of Kuopio, Kuopio, Finland (K.E.O.Å.) 
JPET/2002/48025

Running title: Recognition of $\mathrm{OX}_{1}$ and $\mathrm{OX}_{2}$ receptors by orexins peptides

Corresponding author: Jyrki Kukkonen, Department of Neuroscience, Physiology, Uppsala University, BMC, P.O. Box 572, SE-75123 Uppsala, Sweden

Tel.: +46-18-471 4171; Fax: +46-18-50 63 57; email: jkukkone@fysiologi.uu.se

Number of text pages $=31$

Number of tables $=5$

Number of figures $=6$

Number of references $=31$

Number of words in the Abstract $=245$

Number of words in the Introduction $=740$

Number of words in the Discussion $=1496$

ABBREVIATIONS: $\left[\mathrm{Ca}^{++}\right]_{\mathrm{e}}$, extracellular free calcium concentration; $\left[\mathrm{Ca}^{++}\right]_{\mathrm{i}}$, intracellular free calcium concentration; CNS, central nervous system; $\Delta\left[\mathrm{Ca}^{++}\right]_{\mathrm{i}}$, change in $\left[\mathrm{Ca}^{++}\right]_{\mathrm{i}}\left(\left[\mathrm{Ca}^{++}\right]_{\mathrm{i} / \text { stimulated }}\right.$ $\left.-\left[\mathrm{Ca}^{++}\right]_{\mathrm{i} / \text { basal }}\right) ; \mathrm{EC}_{50}$, concentration producing half-maximal response; EGTA, ethylene glycolbis( $\beta$-aminoethyl ether)N,N,N',N'-tetraacetic acid; $\mathrm{IP}_{3}$, inositol-1,4,5-trisphosphate; $N$, the number of batches of cells for the measurements; $\mathrm{n}_{\mathrm{Hill}}$, Hill-coefficient; $\mathrm{pEC} \mathrm{C}_{50},-\log \left(\mathrm{EC}_{50}\right)$; probenecid, $p$-(dipropylsulfamoyl)benzoic acid; TBM, TES Buffered Medium; TES, 2-([2hydroxy-1,1-bis(hydroxymethyl)ethyl]amino) ethane sulfonic acid

Section assignment: Cellular \& Molecular 
JPET/2002/48025

\begin{abstract}
In this study, we have compared the abilities of orexin-A and orexin-B and variants of orexin-A to activate different $\mathrm{Ca}^{++}$responses (influx and release) in human $\mathrm{OX}_{1}$ and $\mathrm{OX}_{2}$ receptor expressing CHO cells. Responses mediated by activation of both receptor subtypes with either orexin-A or -B were primarily dependent on extracellular $\mathrm{Ca}^{++}$, suggesting similar activation of $\mathrm{Ca}^{++}$influx as we have previously shown for orexin-A and $\mathrm{OX}_{1}$ receptor. Amino-acid-wise truncation of orexin-A reduced its ability to activate $\mathrm{OX}_{1}$ and $\mathrm{OX}_{2}$ receptors, but the response mediated by the $\mathrm{OX}_{2}$ receptor was more resistant to truncation than the response mediated by the $\mathrm{OX}_{1}$ receptor. We also performed a sequential replacement of amino acids 14-26 with alanine in the truncated orexin-A variant orexin- $\mathrm{A}_{14-33}$. Replacement of the same amino acids produced a fall in the potency for each receptor subtype, but the reduction was less prominent for the $\mathrm{OX}_{2}$ receptor. The most marked reduction was produced by the replacement of Leu20, Asp25 and His26 with alanine. Interestingly, extracellular $\mathrm{Ca}^{++}$-dependence of responses to some of the mutated peptides was different to those of orexin-A and -B. The mutagenesis also suggests that although the determinants required from orexin-A for binding to and activation of the receptor are highly conserved between the orexin receptor subtypes, the $\mathrm{OX}_{2}$ receptor requires fewer determinants. This might in part explain why orexin-B has the affinity and potency equal to orexin-A for this subtype, although it has 10-100 fold lower affinity and potency for the $\mathrm{OX}_{1}$ receptor.
\end{abstract}




\section{JPET/2002/48025}

Recently, two novel hypothalamic peptides were isolated and subsequently named orexin-A and orexin-B (Sakurai et al., 1998) or hypocretin-1 and hypocretin-2 (de Lecea et al., 1998). Despite some initial confusion, orexin-A should now be considered identical to hypocretin-1 and orexinB to hypocretin-2. Orexins act as agonists on two G-protein-coupled receptors called $\mathrm{OX}_{1}$ and $\mathrm{OX}_{2}$ receptors. Increased wakefulness and reduced sleep is a well-demonstrated response to central administration of orexin, and disruption of central orexinergic signaling leads to the sleep disorder narcolepsy in animal models and probably also in man (reviewed in Beuckmann and Yanagisawa, 2002; Kukkonen et al., 2002; Sutcliffe and de Lecea, 2002). The other physiological roles for orexins may be regulation of energy homeostasis and stress response, probably both via central and peripheral mechanisms (reviewed in Willie et al., 2001; Beuckmann and Yanagisawa, 2002; Kirchgessner, 2002; Kukkonen et al., 2002; Smart and Jerman, 2002).

The two orexin peptides, orexin-A and -B, are both products of the same precursor peptide, preproorexin, cleavage of which results in equimolar amounts of orexin-A and orexinB. Orexin-A is composed of 33 amino acids and it contains two disulfide bridges, whereas orexin-B is a linear peptide of 28 residues (Sakurai et al., 1998). Though a product of a different part of the precursor peptide, orexin-B shows a $46 \%$ sequence identity with orexin-A, and these two peptide sequences seem to have arisen through duplication of a single sequence (Alvarez and Sutcliffe, 2002). Most striking is the homology in the more C-terminal parts of the peptide, which could make orexin-B an N-terminally truncated variant of orexin-A. The secondary structure of orexin-A is not known but orexin-B has been determined to consist of two $\alpha$-helices in $60-80^{\circ}$ angle to each other (Lee et al., 1999). Orexin-A is much more lipophilic than orexin-B and it is also more stable in blood and cerebrospinal fluid (Kastin and Akerstrom, 1999). Yet, 


\section{JPET/2002/48025}

the CNS (central nervous system) orexin-B levels are consistently 2-5 times higher than orexinA levels (Mondal et al., 1999a; Mondal et al., 1999b; Date et al., 2000a; Date et al., 2000b).

Orexins act as agonists on two G-protein-coupled receptors called $\mathrm{OX}_{1}$ and $\mathrm{OX}_{2}$ receptors. Both of these subtypes show a high (91-98\%) interspecies conservation between different mammalians. Human variants of $\mathrm{OX}_{1}$ and $\mathrm{OX}_{2}$ receptors share a $64 \%$ sequence identity. Many studies suggest $\mathrm{Ca}^{++}$influx as the most immediate cellular response to orexin receptor activation in different systems (van den Pol et al., 1998; van den Pol, 1999; Lund et al., 2000; Hirota et al., 2001; Kukkonen and Åkerman, 2001; Uramura et al., 2001; Holmqvist et $a l .$, 2002). This $\mathrm{Ca}^{++}$influx may in some systems occur via protein kinase $\mathrm{C}$-dependent activation of voltage-gated $\mathrm{Ca}^{++}$channels (van den Pol et al., 1998; Uramura et al., 2001; Xu et al., 2002) but a different type of $\mathrm{Ca}^{++}$channel has been implicated in other systems (Lund et al., 2000; Kukkonen and Åkerman, 2001). In the CNS, the most prominent response to orexin application is an increase in synaptic activity (reviewed in Beuckmann and Yanagisawa, 2002; Kukkonen et al., 2002). The putative role of increased $\mathrm{Ca}^{++}$influx for this process is largely unclear (reviewed in Kukkonen et al., 2002). Orexin receptor subtypes are somewhat differentially distributed (reviewed in Willie et al., 2001; Kukkonen et al., 2002; Smart and Jerman, 2002), but since there is yet no evidence of subtype selective signaling, it is difficult to predict the significance of this difference.

When $\mathrm{Ca}^{++}$or inositol phosphate responses are measured in $\mathrm{CHO}$ (Chinese hamster ovary), PC12 or Neuro-2a cells recombinantly expressing orexin receptors, orexin-A is 10-100 times more potent than orexin-B on the $\mathrm{OX}_{1}$ receptors, whereas both orexins are equipotent on the $\mathrm{OX}_{2}$ receptors (Sakurai et al., 1998; Smart et al., 1999; Okumura et al., 2001; Holmqvist et al., 2002). These potencies appear to be direct reflections of the binding affinities (Sakurai et 


\section{JPET/2002/48025}

al., 1998), suggesting that in spite of the similarities between the orexin receptors there are interesting differences in the ligand binding domains. To further examine the parameters required for the orexin peptide-receptor interaction, we have in this study investigated the determinants of orexin-A required to activate $\mathrm{OX}_{1}$ and $\mathrm{OX}_{2}$ receptors. Truncated and alaninesubstituted orexin-A peptides have been tested for their ability to induce $\mathrm{Ca}^{++}$elevations in $\mathrm{CHO}-\mathrm{K} 1$ cells heterologously expressing $\mathrm{OX}_{1}$ or $\mathrm{OX}_{2}$ receptors. The results suggest that the structures responding to orexin-A are highly conserved between $\mathrm{OX}_{1}$ and $\mathrm{OX}_{2}$ receptors but also that there are some clear differences between these receptors. 
JPET/2002/48025

\section{Methods}

Cell Culture. CHO-hOX ${ }_{1}-\mathrm{C} 1$ cells were produced as described in (Lund et al., 2000). $\mathrm{CHO}-\mathrm{hOX}_{2}-\mathrm{C} 1$ cells were produced in similar way; the clones used expressed receptors at approximately the same level, as determined with $\left[{ }^{125} \mathrm{I}\right]$ orexin- $\mathrm{A}$ binding. $\mathrm{CHO}-\mathrm{hOX} \mathrm{X}_{1}-\mathrm{C} 1$ and CHO-hOX $2-\mathrm{C} 1$ cells were grown in Ham's F12 medium (Gibco, Paisley, UK) supplemented with $100 \mathrm{U} / \mathrm{ml}$ penicillin G (Sigma Chemical Co., St. Louis, MO), 80 U/ml streptomycin (Sigma), $400 \mu \mathrm{g} / \mathrm{ml}$ geneticin (G418; Gibco) and $10 \%$ (v/v) fetal calf serum (Gibco) at $37^{\circ} \mathrm{C}$ in $5 \% \mathrm{CO}_{2}$ in an air ventilated humidified incubator in $260 \mathrm{ml}$ plastic culture flasks $\left(75 \mathrm{~cm}^{2}\right.$ bottom area; Nunc A/S, Roskilde, Denmark). For fluorometry, the cells were grown on circular plastic culture dishes (inner diameter, $94 \mathrm{~mm}$; Nunc).

Drugs. EGTA (ethylene glycol-bis[ $\beta$-aminoethyl ether]N,N,N',N'-tetraacetic acid) and probenecid ( $p$-[dipropylsulfamoyl]benzoic acid) were purchased from Sigma (Natick, MA) and Fura-2 acetoxymethyl ester and fluo-3 acetoxymethyl ester from Molecular Probes Inc. (Eugene, OR). Human orexin-A and -B were from Peninsula Laboratories Europe Ltd. (St. Helens, UK) or Neosystem (Strasbourg, France) and digitonin was from Merck AG (Darmstadt, Germany).

Peptide synthesis. To avoid investigation of complex secondary structure changes caused by disulfide-bridge removals, we initially truncated orexin-A N-terminally to produce orexin- $\mathrm{A}_{14-33}$, which is devoid of disulfide bonds, yet it has substantial activity on $\mathrm{OX}_{1}$ and $\mathrm{OX}_{2}$ receptors. A previous study has suggested that a significant part of the potency lost by truncation of orexin-A to orexin- $\mathrm{A}_{15-33}$ is caused by the loss of the disulfide-bridges (Okumura et al., 2001). All the further mutagenesis was done on orexin- $\mathrm{A}_{14-33}$. We both performed a further stepwise $\mathrm{N}$ terminal truncation of this peptide and one-by-one replacement of amino acids with alanine 


\section{JPET/2002/48025}

("alanine scan") (table 1, fig. 1). The truncated and alanine-scanned orexin-A-peptides were synthesized using Fmoc (9-fluorenylmethoxycarbonyl) synthesis protocols with double or triple coupling reactions using TBTU (2-[H-benzotriazol-1-yl]-1,1,3,3-tetramethyluronium tetrafluoroborate) as the activator on a Symphony synthesizer (Rainin Instrument Co., Woburn, MA). Purifications were performed by reverse phase-HPLC on a Delta-Pak C18 column (15 $\mu \mathrm{m}$ - $100 \AA-25 \times 100$ mm) (Waters, Milford, MA) using a Waters liquid chromatography system consisting of Model 600 solvent delivery pump, a Rheodine injector and an automated gradient controller (solvent A: $\mathrm{H}_{2} \mathrm{O}-0.125 \%$ TFA [trifluoroacetic acid]; solvent $\mathrm{B}$ : $\mathrm{CH}_{3} \mathrm{CN}-0.1 \%$ TFA; gradient: $15 \%$ B to $60 \%$ B in 20 min). Detection was carried out using Model M2487 variable wavelength UV detector connected to the Waters Millenium software control unit. The Quality Control was performed by analytical reverse phase-HPLC on a Waters Delta-Pak C18 (5 $\mu$ m $100 \AA-150 \times 3.9 \mathrm{~mm}$ ) column (same solvents as above; gradient: $0 \% \mathrm{~B}$ to $60 \% \mathrm{~B}$ in $20 \mathrm{~min}$ ) using a Waters Alliance 2690 Separation Module equipped with a Waters 996 Photodiode Array Detector and by MALDI-TOF (matrix-assisted laser desorption ionization time-of-flight) mass spectrometry using a Voyager-DE instrument (PerSeptive Biosystems, Framinghan, MA).

Media. The TES Buffered Medium (TBM) consisted of $137 \mathrm{mM} \mathrm{NaCl}, 5 \mathrm{mM} \mathrm{KCl,} 1$ $\mathrm{mM} \mathrm{CaCl}_{2}, 1.2 \mathrm{mM} \mathrm{MgCl} 2,0.44 \mathrm{mM} \mathrm{KH}_{2} \mathrm{PO}_{4}, 4.2 \mathrm{mM} \mathrm{NaHCO} 3,10 \mathrm{mM}$ glucose, $1 \mathrm{mM}$ probenecid and $20 \mathrm{mM}$ 2-([2-hydroxy-1,1-bis(hydroxymethyl)ethyl]amino) ethane sulfonic acid (TES) adjusted to $\mathrm{pH} 7.4$ with $\mathrm{NaOH}$.

$\mathrm{Ca}^{++}$measurements. Both the fluorescent $\mathrm{Ca}^{++}$indicators fura- 2 and fluo- 3 were used to monitor changes in intracellular $\left[\mathrm{Ca}^{++}\right]\left(\left[\mathrm{Ca}^{++}\right]_{\mathrm{i}}\right)$ since they offer detection of low and high $\mathrm{Ca}^{++}$ elevations, respectively, with high accuracy due to different $\mathrm{K}_{\mathrm{d}^{-}}$values for $\mathrm{Ca}^{++}$binding. The $\mathrm{K}_{\mathrm{d}}$ of $224 \mathrm{nM}$ was used for fura- 2 whereas the $\mathrm{K}_{\mathrm{d}}$ of $1000 \mathrm{nM}$ was determined for fluo- 3 in 


\section{JPET/2002/48025}

simultaneous measurement with fura-2. The low responses of the truncated C-terminal orexin-Apeptides were thus determined using fura- 2 whereas all the other experiments were performed using fluo-3. It should be noted that the $\mathrm{K}_{\mathrm{d}}$-value of the indicator does not affect the relative $\mathrm{EC}_{50}$-values or the maximum responses determined. For the experiments, the cells were harvested using phosphate buffered saline containing $0.2 \mathrm{~g} / \mathrm{l}$ EDTA, loaded with fura-2 acetoxymethyl ester or fluo-3 acetoxymethyl ester $\left(4 \mu \mathrm{M}, 20 \mathrm{~min}, 37^{\circ} \mathrm{C}\right)$ in the culture medium (Ham-F12) supplemented with $10 \mu \mathrm{g} / \mathrm{ml}$ bovine serum albumin and $1 \mathrm{mM}$ probenecid and stored on ice as pellets (medium removed). For the measurement of intracellular free calcium, one pellet was resuspended in $\mathrm{TBM}$ at $37^{\circ} \mathrm{C}$. The fluorescence was monitored in a stirred quartz microcuvette in a thermostated cell holder of either a Hitachi F-2000 or F-4000 fluorescence spectrophotometer at the wavelengths 340 or 340/380 (excitation), 505 (emission) for fura- 2 or $480 \mathrm{~nm}$ (excitation), $540 \mathrm{~nm}$ (emission) for fluo-3. Experiments were calibrated by adding 60 $\mu \mathrm{g} / \mathrm{ml}$ digitonin, which gives the maximum value of fluorescence, and $10 \mathrm{mM}$ EGTA, which gives the minimum value of fluorescence. The leaked fura- 2 and fluo- 3 were measured in separate experiments by adding $10 \mathrm{mM}$ EGTA, which chelates $\mathrm{Ca}^{++}$bound to extracellular indicator. The corrected fluorescence values were used to calculate $\left[\mathrm{Ca}^{++}\right]_{\mathrm{i}}$.

Calculations and data analysis. The extracellular free $\left[\mathrm{Ca}^{++}\right]\left(\left[\mathrm{Ca}^{++}\right]_{\mathrm{e}}\right)$ was determined as described in (Lund et al., 2000). Thus, addition of $1.5 \mathrm{mM}$ EGTA in TBM gave a $\left[\mathrm{Ca}^{++}\right]_{\mathrm{e}}$ of approximately $140 \mathrm{nM}$. Values are given as mean \pm S.E.M. unless otherwise indicted; $N$ refers to the number of batches of cells on which the measurements were performed. Non-linear curvefitting was performed using SigmaPlot for Windows 4.01 (Jandel Scientific, Corte Madera, CA). The difference in the potency $\left(\mathrm{EC}_{50}\right)$ and activity (max response) of orexin- $\mathrm{A}$ and orexin- $\mathrm{B}$ to elevate $\mathrm{Ca}^{++}$in $1 \mathrm{mM}$ and $140 \mathrm{nM}\left[\mathrm{Ca}^{++}\right]_{\mathrm{e}}$ (table 2) was evaluated using Student's paired two- 


\section{JPET/2002/48025}

tailed $t$ test. The differences in the activity (maximum response) between different peptides was evaluated using Student's non-paired two-tailed $t$ test. 
JPET/2002/48025

\section{Results}

Orexin-A and -B differentially activate $\mathrm{OX}_{1}$ and $\mathrm{OX}_{2}$ receptors. As shown previously (Lund et al., 2000; Holmqvist et al., 2001; Kukkonen and Åkerman, 2001), orexin-A caused large elevations in intracellular $\left[\mathrm{Ca}^{++}\right]$in $\mathrm{OX}_{1}$ receptor-expressing $\mathrm{CHO}-\mathrm{K} 1$ cells (table 2). Orexin-B was 7-fold less potent (table 2 and 3, fig. 2A). No difference in the potency between the ligands was seen for the $\mathrm{OX}_{2}$ receptor (table 2 and 3, fig. 2B). We have previously shown that $\mathrm{OX}_{1}$-mediated $\mathrm{Ca}^{++}$-response to low concentrations of orexin-A requires extracellular $\mathrm{Ca}^{++}$ in CHO cells (Lund et al., 2000; Holmqvist et al., 2001; Kukkonen and Åkerman, 2001). This is not specific for orexin-A as an external $\mathrm{Ca}^{++}$-dependence was also seen with respect to both orexin-A and -B response with both $\mathrm{OX}_{1}$ and $\mathrm{OX}_{2}$ receptors (table 2; fig. 2). Reduction in extracellular $\mathrm{Ca}^{++}$caused a considerable increase in the $\mathrm{n}_{\mathrm{Hill}}$ value for all combinations of ligand/receptor. This change was largest for the effect of orexin-B on the $\mathrm{OX}_{2}$ receptor.

With each batch of cells, concentration-response relationships were determined with both orexin-A and orexin-B in normal $(1 \mathrm{mM})$ and low $(140 \mathrm{nM})$ extracellular $\mathrm{Ca}^{++}$. This allows comparison within individual batches of cells and the slight variance between the batches of cells does not distort the results. From these data the significancies for any difference between high and low extracellular $\mathrm{Ca}^{++}$and orexin-A and orexin-B were calculated using the paired $t$ test (table 3). These data confirm the fact that there is a difference in the potency between orexin- $\mathrm{A}$ and $-\mathrm{B}$ for the $\mathrm{OX}_{1}$ receptor but not for the $\mathrm{OX}_{2}$ receptor. Orexin-B appears to give a slightly (10-24\%) lower maximum response than orexin-A in all the cases. A right-shift in the $\mathrm{EC}_{50}$ values of both orexin- $\mathrm{A}$ and $-\mathrm{B}$ is seen upon reduction of extracellular $\mathrm{Ca}^{++}$, but the 
JPET/2002/48025

maximum responses appear unaffected. Notably, the shift appears lower for orexin-B than for orexin-A with both $\mathrm{OX}_{1}$ and $\mathrm{OX}_{2}$ receptors.

\section{C-terminal Orexin-A peptides are agonistic for the $\mathrm{OX}_{1}$ and $\mathrm{OX}_{2}$ receptors}

C-terminal truncation of orexin-A to orexin- $\mathrm{A}_{14-33}$ (fig. 1) increased the $\mathrm{EC}_{50}$ to $27 \mathrm{nM}$ from 4 $\mathrm{nM}\left(\mathrm{OX}_{1}\right)$ or $7 \mathrm{nM}\left(\mathrm{OX}_{2}\right)$ (tables 4 and 5). The maximum response, however, was not affected, as calculated using non-paired $t$ test. The effect of a further reduction in the peptide length is shown in fig. 3. The response to $100 \mathrm{nM}$ peptide fell when the peptide length was reduced to 18 amino acids (orexin- $\mathrm{A}_{16-33}$ ) (fig. $3 \mathrm{~A}$ and $\mathrm{B}$ ). Further truncation to 15 amino acids (orexin- $\mathrm{A}_{19-33}$ ) completely abolished the $\mathrm{Ca}^{++}$response to $100 \mathrm{nM}$ peptide (fig. 3A and B). In a similar manner, both $\mathrm{OX}_{1}$ - and $\mathrm{OX}_{2}$-expressing cells ceased responding to $1 \mu \mathrm{M}$ of the peptide when its length was reduced to 12 amino acids (orexin- $\mathrm{A}_{22-33}$ ), though the response to $10 \mu \mathrm{M}$ peptide was retained (fig. 3A and B). With further truncation, the fall in activity was eminent in the $\mathrm{OX}_{1^{-}}$ expressing cells, and the $\mathrm{C}$-terminal decapeptide (orexin- $\mathrm{A}_{24-33}$ ) gave no response even at the concentration of $10 \mu \mathrm{M}$. The decline in activity with reduced peptide length was markedly lower with $\mathrm{OX}_{2}$-receptors. At $10 \mu \mathrm{M}$, the nonapeptide (orexin- $\mathrm{A}_{25-33}$ ) gave a robust response, and a slight response was still observed with the heptapeptide (orexin- $\mathrm{A}_{27-33}$ ) but not with the hexapeptide (orexin- $\mathrm{A}_{28-33}$ ) (fig. $3 \mathrm{~A}$ and $\mathrm{B}$ ).

To evaluate the role of individual amino acid residues in the C-terminal orexin-A peptide for the binding and activation of the orexin receptors, we performed an alanine-scan of the residues 14-26 in the orexin- $\mathrm{A}_{14-33}$ (table 1). Similar areas/residues of importance in orexin-A were observed both for $\mathrm{OX}_{1}$ and $\mathrm{OX}_{2}$ receptors. Replacements of Arg15, Leu16 or Tyr17 with alanine caused a 2 -fold reduction in the potency of the peptide (tables 4 and 5, fig. 4). OX receptor may be less sensitive to the mutation of Tyr17 than $\mathrm{OX}_{2}$ receptor. More dramatic 


\section{JPET/2002/48025}

reduction in the potency was seen with mutation of Leu20 to alanine: The potency for the $\mathrm{OX}_{1}$ receptor was reduced 25-fold and the potency for the $\mathrm{OX}_{2}$ receptor 11 -fold (tables 4 and 5, figs. 4 and 5A). Remarkably, neither the mutation of the Leu19 nor His 21 markedly affected the potency of the peptide (tables 4 and 5, figs. 4 and 5B). Mutation of Asn25 and His26 to alanine caused a progressive reduction in the potency, which was more pronounced for the $\mathrm{OX}_{1}$ receptor (tables 4 and 5, figs. 4 and 5C). Thus, the results with $\mathrm{OX}_{1}$ and $\mathrm{OX}_{2}$ receptors are largely similar except for differences with some mutations (Tyr17Ala, Leu20Ala, Asn25Ala, His26Ala).

Some of the peptides, as also orexin-A, display high slope factors $\left(\mathrm{n}_{\text {Hill }}\right)($ tables 4 and 5, fig. 5B). We have previously shown that $\mathrm{Ca}^{++}$influx can amplify the phospholipase $\mathrm{C}$ response at low concentrations of orexin-A in $\mathrm{CHO}^{-O X}{ }_{1}$ cells (Lund et al., 2000). Therefore, different slope factors could indicate different degree of synergism between the two signals to phospholipase $\mathrm{C}$ and thus a differential ability to activate $\mathrm{Ca}^{++}$influx and $\mathrm{Ca}^{++}$release responses. We therefore tested the ability of chosen peptides to elevate intracellular $\mathrm{Ca}^{++}$in low $(140 \mathrm{nM})$ extracellular $\left[\mathrm{Ca}^{++}\right]$. The potency of orexin-A was shifted 10-14-fold to the right and the potency of orexin-B somewhat less (6-fold) by the reduction of extracellular $\left[\mathrm{Ca}^{++}\right]$(fig. 6). Orexin- $\mathrm{A}_{14-33}$ was affected in a similar degree as orexin-A (11-fold shift; fig. 6). In contrast, orexin- $A_{14-33} R 15 A$ was much less affected (4-5-fold shift), even less than orexin-B. On the other hand, the reduction in potency for orexin- $\mathrm{A}_{14-33} \mathrm{~L} 16 \mathrm{~A},-\mathrm{Y} 17 \mathrm{~A}$ and $-\mathrm{H} 21 \mathrm{~A}$ was much larger (1867 fold), especially in the case of the $\mathrm{OX}_{1}$ receptor. However, the difference in the shift of the $\mathrm{EC}_{50}$ did not correlate with the slope factor. Note that the determination of the $\mathrm{EC}_{50}$ for orexin$\mathrm{A}_{14-33} \mathrm{~L} 20 \mathrm{~A}$ in the low extracellular $\mathrm{Ca}^{++}$was impossible due to its low potency.

We wanted to further confirm that the reduced potency of the mutated/truncated orexin peptides was due to reduced affinity for the orexin receptor. There is no pharmacologically 
JPET/2002/48025

satisfactory binding assay for orexin receptors; at the moment, orexin receptor binding has to be conducted using using radio- or fluorescently labeled orexin-A (an agonist) and intact cells (Kane et al., 2000; Darker et al., 2001; Holmqvist et al., 2001; Smart et al., 2001). Therefore, an alternative qualitative approach was used. For this the cells were exposed to a slightly lower concentration of the peptides than required to give a minimum detectable $\mathrm{Ca}^{++}$response. After a 2-minute preincubation, orexin-A or orexin- $\mathrm{A}_{14-33}$ at different concentrations was added. Neither orexin-A nor any of the peptides inhibited subsequent response to orexin-A or orexin- $\mathrm{A}_{14-33}$ confirming that the reduced potency of the peptides was indeed due to reduced affinity. It should be noted that this approach cannot give an assumption of how much the affinity is reduced, only that the binding affinity is not higher than the $\mathrm{EC}_{50}$. 
JPET/2002/48025

\section{Discussion}

In the present study, we have investigated the differences between $\mathrm{OX}_{1}$ and $\mathrm{OX}_{2}$ receptors with respect to the specificity of activation by modified orexin peptides. The results obtained in this study indicate that the both $\mathrm{OX}_{1}$ and $\mathrm{OX}_{2}$ receptors require very similar determinants from orexin-A to allow binding to and activation of the receptor, which indicates that analogous domains of $\mathrm{OX}_{1}$ and $\mathrm{OX}_{2}$ receptors interact with orexin-A. However, some interesting differences are seen, the most obvious of which being the less strict requirements of the $\mathrm{OX}_{2}$ receptor for ligand binding.

As also previously shown, orexin-B had potency equal to orexin-A for the $\mathrm{OX}_{2}$ receptor, but 10-100-fold lower relative potency for the $\mathrm{OX}_{1}$ receptor. Thus, the $\mathrm{OX}_{2}$ receptor cannot distinguish between orexin- $\mathrm{A}$ and $-\mathrm{B}$ as the $\mathrm{OX}_{1}$ receptor does. The $\mathrm{OX}_{1}$ receptor was much more affected by the N-terminal truncation of orexin-A than the $\mathrm{OX}_{2}$ receptor. The first truncation of orexin-A to orexin- $\mathrm{A}_{14-33}$, which removes the sulfhydryl bridges, essentially abolished the difference between $\mathrm{OX}_{1}$ and $\mathrm{OX}_{2}$ receptors with respect to orexin-A. Since orexinB is N-terminally more or less truncated as compared to orexin-A, these data from truncation of orexin-A may in part explain why orexin-B is as potent as orexin-A on the $\mathrm{OX}_{2}$ receptor. However, domains interacting with the most N-terminal portion of orexin-A are not the only difference between the two receptors as the $\mathrm{OX}_{2}$ receptor also resisted further truncation far better than the $\mathrm{OX}_{1}$ receptor. Alanine-scan identified residues of particular importance for orexin receptor activation. These residues were the same with respect to the activation of both $\mathrm{OX}_{1}$ and $\mathrm{OX}_{2}$ receptors, but the potency for the $\mathrm{OX}_{2}$ receptor was less markedly affected. This further supports the notion of less strict requirements for binding and activation of the $\mathrm{OX}_{2}$ receptor. 


\section{JPET/2002/48025}

Human $\mathrm{OX}_{1}$ and $\mathrm{OX}_{2}$ display 64\% overall sequence identity (Sakurai et al., 1998). An even higher degree of identity and similarity are found between the proximal N-termini and the extracellular loop 1 of the receptors. This might suggest that these parts of the receptors are important for the orexin binding, as is also suggested by the almost complete loss of orexin binding caused by the Glu54Lys (position homologous to Glu54 in human $\mathrm{OX}_{2}$ receptor) mutation in the canine $\mathrm{OX}_{2}$ receptor (Hungs et al., 2001). No obvious differences, which could explain the different behavior of $\mathrm{OX}_{1}$ and $\mathrm{OX}_{2}$ receptor, are seen.

All the peptides displayed slope factors above one and in addition many of the truncated and alanine-scanned peptides, though not orexin-A itself, displayed slope factors $\left(\mathrm{n}_{\text {Hill }}\right)$ above 2.5. This may suggest cooperative binding, which in the case of G-protein-coupled receptors would indicate formation/presence of receptor di-/oligomers. However, this has not been seen in binding studies (Sakurai et al., 1998)(Holmqvist et al., unpublished), but the unsatisfactory conditions for the binding assay (see Results) may mask this. Apparent cooperativity could also originate from the functional level. We have previously reported that orexin-A activates $\mathrm{Ca}^{++}$ influx as a primary response mechanism. $\mathrm{Ca}^{++}$influx and an unknown signal from the receptor act synergistically to activate phopholipase $\mathrm{C}$, since no phospholipase $\mathrm{C}$ activation is seen with $\mathrm{Ca}^{++}$influx alone, and in the absence of $\mathrm{Ca}^{++}$influx phospholipase $\mathrm{C}$ is activated only at 100 times higher concentration of orexin-A (Lund et al., 2000; Kukkonen and Åkerman, 2001). We hypothesized that the reduced ability of some of the peptides to activate one of the $\mathrm{Ca}^{++}$ responses, influx or release, could explain the high slope factors. Our experiments indeed confirmed that there are clear differences in the relative potencies between different mutant peptides towards these responses. The $\mathrm{Ca}^{++}$responses mediated by the $\mathrm{OX}_{2}$ receptor were for most of the peptides less affected by removal of extracellular $\mathrm{Ca}^{++}$than the responses via $\mathrm{OX}_{1}$ 


\section{JPET/2002/48025}

receptor. However, these differences do not explain the apparent cooperativity, and other explanations may be required.

It has been shown before, that $\mathrm{N}$-terminal truncation of orexin-A to orexin- $\mathrm{A}_{15-33}(19$ amino acids), which completely eliminates all cycteines, reduces the potency for the $\mathrm{OX}_{1}$ receptor 60-170-fold (Darker et al., 2001; Okumura et al., 2001) but the reduction is only 20fold for the $\mathrm{OX}_{2}$ receptor (Okumura et al., 2001). In the present study, the potency of orexin-A was decreased only 7 - respectively 4-fold for the $\mathrm{OX}_{1}$ and $\mathrm{OX}_{2}$ receptors upon truncation to orexin- $\mathrm{A}_{14-33}$. Darker et al. (2001) have characterized the effect of further truncation of orexin-A on the activation of the $\mathrm{OX}_{1}$ receptor: truncation of orexin-A to $19,17,16,15,10$ and 5 amino acids progressively reduced the response to $10 \mu \mathrm{M}$ peptide, and 5 and 10 amino acid-long peptides were inactive. In contrast to this, we did not observe any significant reduction in the maximum response until the chain length was reduced to 12 or 11 amino acids. In the present study, the shortened chain instead decreased the potency (increased the $\mathrm{EC}_{50}$ ). This apparent discrepancy could be caused by somewhat higher expression level in our CHO cells than those used in (Darker et al., 2001). In our CHO cells the $\mathrm{EC}_{50}$-value for orexin-A is more than 10-fold lower than the binding affinity for $\mathrm{OX}_{1}$ receptors (Holmqvist et al., unpublished) as compared to only a 6-fold difference in (Darker et al., 2001). Darker et al. (2001) have also shown that truncation of orexin- $\mathrm{A}$ to orexin- $\mathrm{A}_{15-33}$ abolishes this difference in the $\mathrm{EC}_{50}$ and binding affinity; thus this truncation may decrease both the binding affinity and the efficacy of the peptide. Our semiquantitative estimation of the binding affinity suggests that further truncation may only reduce the binding affinity and not the efficacy. In other words, once bound, both orexin- $\mathrm{A}_{14-33}$ and the shorter peptides may have similar ability to activate the receptor. The most C-terminal amino acids may be the most important for the activation of the receptor whereas the additional 


\section{JPET/2002/48025}

N-terminal amino acids may increase the binding affinity and efficacy by making contact with the receptor and stabilizing orexin-A structure. The importance of the C-terminus is evident since this area is highly conserved between orexin-A and orexin-B (fig. 1). The present results support the view that for this kind of studies, high receptor expression levels are useful.

Alanine-scan of residues $14-26$ in orexin- $\mathrm{A}_{14-33}$ identified three areas of interest, which were the same in both $\mathrm{OX}_{1}$ and $\mathrm{OX}_{2}$ receptors: amino acids 15-17, 20 and 25-26. Alanine-scan of orexin- $\mathrm{A}_{15-33}$ was performed in (Darker et al., 2001) with results similar to the results in the present study with respect to $\mathrm{OX}_{1}$ receptor activation. This study also showed that the receptor response is extremely sensitive to mutations in the outermost C-terminus (amino acids 26-33), as can be expected from the highly similar C-termini of orexin-A and -B. In contrast to Darker et al. (2001), we failed to detect any decrease in the potency by mutation of residues 21-24. Neither we nor Darker et al. (2001) detected any mutation that would markedly increase the potency of the peptide. The most interesting mutation is the Leu20Ala, which causes an over 10fold drop in the potency of the orexin- $\mathrm{A}_{14-33}$. In contrast to the findings of Darker et al. (2001) we saw almost no effect of the mutation of the adjacent amino acids, Leu19 or His21. Mutation of a leucine to alanine does not cause any change in the charge of the peptide neither can the effect be explained by steric hindrance, which should instead be diminished by the less bulky alanine. Therefore, the effect of this mutation is likely to affect the secondary or tertiary structure of orexin- $\mathrm{A}_{14-33}$ rather than the interaction with the orexin-binding site. If orexin- $\mathrm{A}$, as orexin-B (Lee et al., 1999), forms an $\alpha$-helical structure in this region then replacement of leucine with alanine should also not have any remarkable effect on the secondary structure. Since the 3D-structure of orexin-A is unknown, no conclusion of its structure and the effects of mutations thereon can be made. The alanine-scanned peptides activated the $\mathrm{OX}_{2}$ receptor with 
JPET/2002/48025

potencies very similar to those for the $\mathrm{OX}_{1}$ receptor. However, the $\mathrm{OX}_{2}$ receptor once again proved less "fussy" in its requirements on the orexin- $\mathrm{A}_{15-33}$ peptide than the $\mathrm{OX}_{1}$ receptor.

Orexin receptor subtypes are somewhat differentially expressed in the CNS and in the periphery, but the significance of this is unknown since no separate cellular functions have been ascribed to the receptor subtypes and the relative amounts of orexin-A versus orexin-B seem rather constant in the different CNS areas (Kukkonen et al., 2002). Therefore, some of the major issues are whether orexin receptor subtypes can couple to different signaling pathways and whether different orexin peptides can cause "signal-trafficking" (Kenakin, 1995) even via a single receptor subtype. The data from the experiments with reduced extracellular $\left[\mathrm{Ca}^{++}\right]$suggest that orexin peptides may have an inherent ability to do this. Also some in vivo and in vitro data suggest that orexin-B is more efficacious than orexin-A (see Kukkonen et al., 2002), which is unexplainable based on the recombinant pharmacology. We propose that the physiological roles of orexins can only be elucidated in the light of much further data on the receptor subtype specificity in ligand binding and signaling pathway activation. 
JPET/2002/48025

\section{References}

Alvarez CE and Sutcliffe JG (2002) Hypocretin is an early member of the incretin gene family. Neurosci Lett 324:169-172.

Beuckmann CT and Yanagisawa M (2002) Orexins: from neuropeptides to energy homeostasis and sleep/wake regulation. J Mol Med 80:329-342.

Darker JG, Porter RA, Eggleston DS, Smart D, Brough SJ, Sabido-David C and Jerman JC (2001) Structure-activity analysis of truncated orexin-A analogues at the orexin-1 receptor. Bioorg Med Chem Lett 11:737-740.

Date Y, Mondal MS, Matsukura S and Nakazato M (2000a) Distribution of orexin-A and orexin-B (hypocretins) in the rat spinal cord. Neurosci Lett 288:87-90.

Date Y, Mondal MS, Matsukura S, Ueta Y, Yamashita H, Kaiya H, Kangawa K and Nakazato M (2000b) Distribution of orexin/hypocretin in the rat median eminence and pituitary. Brain Res Mol Brain Res 76:1-6.

de Lecea L, Kilduff TS, Peyron C, Gao X, Foye PE, Danielson PE, Fukuhara C, Battenberg EL, Gautvik VT, Bartlett FS, Frankel WN, van den Pol AN, Bloom FE, Gautvik KM and Sutcliffe JG (1998) The hypocretins: hypothalamus-specific peptides with neuroexcitatory activity. Proc Natl Acad Sci U S A 95:322-327.

Hirota K, Kushikata T, Kudo M, Kudo T, Lambert DG and Matsuki A (2001) Orexin A and B evoke noradrenaline release from rat cerebrocortical slices. Br J Pharmacol 134:14611466. 
JPET/2002/48025

Holmqvist T, Åkerman KEO and Kukkonen JP (2001) High specificity of human orexin receptors for orexins over neuropeptide Y and other neuropeptides. Neurosci Lett 305:177-180.

Holmqvist T, Åkerman KEO and Kukkonen JP (2002) Orexin signaling in recombinant neuronlike cells. FEBS Lett 526:11-14.

Hungs M, Fan J, Lin L, Lin X, Maki RA and Mignot E (2001) Identification and functional analysis of mutations in the hypocretin (orexin) genes of narcoleptic canines. Genome Res 11:531-539.

Kane JK, Tanaka H, Parker SL, Yanagisawa M and Li MD (2000) Sensitivity of orexin-A binding to phospholipase $\mathrm{C}$ inhibitors, neuropeptide $\mathrm{Y}$, and secretin. Biochem Biophys Res Commun 272:959-965.

Kastin AJ and Akerstrom V (1999) Orexin A but not orexin B rapidly enters brain from blood by simple diffusion. J Pharmacol Exp Ther 289:219-223.

Kenakin T (1995) Agonist-receptor efficacy. II. Agonist trafficking of receptor signals. Trends Pharmacol Sci 16:232-238.

Kirchgessner AL (2002) Orexins in the brain-gut axis. Endocr Rev 23:1-15.

Kukkonen JP, Holmqvist T, Ammoun S and Åkerman KE (2002) Functions of the orexinergic/hypocretinergic system. Am J Physiol Cell Physiol 283:C1567-C1591.

Kukkonen JP and Åkerman KEO (2001) Orexin receptors couple to Ca2+ channels different from store-operated Ca2+ channels. Neuroreport 12:2017-2020.

Lee JH, Bang E, Chae KJ, Kim JY, Lee DW and Lee W (1999) Solution structure of a new hypothalamic neuropeptide, human hypocretin-2/orexin-B. Eur J Biochem 266:831-839. 


\section{JPET/2002/48025}

Lund PE, Shariatmadari R, Uustare A, Detheux M, Parmentier M, Kukkonen JP and Åkerman KEO (2000) The orexin OX1 receptor activates a novel Ca2+ influx pathway necessary for coupling to phospholipase C. J Biol Chem 275:30806-30812.

Mondal MS, Nakazato M, Date Y, Murakami N, Hanada R, Sakata T and Matsukura S (1999a) Characterization of orexin-A and orexin-B in the microdissected rat brain nuclei and their contents in two obese rat models. Neurosci Lett 273:45-48.

Mondal MS, Nakazato M, Date Y, Murakami N, Yanagisawa M and Matsukura S (1999b) Widespread distribution of orexin in rat brain and its regulation upon fasting. Biochem Biophys Res Commun 256:495-499.

Okumura T, Takeuchi S, Motomura W, Yamada H, Egashira Si S, Asahi S, Kanatani A, Ihara M and Kohgo Y (2001) Requirement of intact disulfide bonds in orexin-A-induced stimulation of gastric acid secretion that is mediated by OX1 receptor activation. Biochem Biophys Res Commun 280:976-981.

Sakurai T, Amemiya A, Ishii M, Matsuzaki I, Chemelli RM, Tanaka H, Williams SC, Richardson JA, Kozlowski GP, Wilson S, Arch JR, Buckingham RE, Haynes AC, Carr SA, Annan RS, McNulty DE, Liu WS, Terrett JA, Elshourbagy NA, Bergsma DJ and Yanagisawa M (1998) Orexins and orexin receptors: a family of hypothalamic neuropeptides and $\mathrm{G}$ protein-coupled receptors that regulate feeding behavior. Cell 92:573-585.

Smart D and Jerman J (2002) The physiology and pharmacology of the orexins. Pharmacol Ther 94:51-61.

Smart D, Jerman JC, Brough SJ, Rushton SL, Murdock PR, Jewitt F, Elshourbagy NA, Ellis CE, Middlemiss DN and Brown F (1999) Characterization of recombinant human orexin 
JPET/2002/48025

receptor pharmacology in a Chinese hamster ovary cell-line using FLIPR. $\mathrm{Br} J$

Pharmacol 128:1-3.

Smart D, Sabido-David C, Brough SJ, Jewitt F, Johns A, Porter RA and Jerman JC (2001) SB334867-A: the first selective orexin-1 receptor antagonist. Br J Pharmacol 132:11791182.

Sutcliffe JG and de Lecea L (2002) The hypocretins: setting the arousal threshold. Nat Rev Neurosci 3:339-349.

Uramura K, Funahashi H, Muroya S, Shioda S, Takigawa M and Yada T (2001) Orexin-a activates phospholipase $\mathrm{C}$ - and protein kinase $\mathrm{C}$-mediated $\mathrm{Ca} 2+$ signaling in dopamine neurons of the ventral tegmental area. Neuroreport 12:1885-1889.

van den Pol AN (1999) Hypothalamic hypocretin (orexin): robust innervation of the spinal cord. J Neurosci 19:3171-3182.

van den Pol AN, Gao XB, Obrietan K, Kilduff TS and Belousov AB (1998) Presynaptic and postsynaptic actions and modulation of neuroendocrine neurons by a new hypothalamic peptide, hypocretin/orexin. J Neurosci 18:7962-7971.

Willie JT, Chemelli RM, Sinton CM and Yanagisawa M (2001) To eat or to sleep? orexin in the regulation of feeding and wakefulness. Annu Rev Neurosci 24:429-458.

Xu R, Wang Q, Yan M, Hernandez M, Gong C, Boon WC, Murata Y, Ueta Y and Chen C (2002) Orexin-A Augments Voltage-Gated Ca(2+) Currents and Synergistically Increases Growth Hormone (GH) Secretion with GH-Releasing Hormone in Primary Cultured Ovine Somatotropes. Endocrinology 143:4609-4619. 
JPET/2002/48025

\section{Footnotes}

This study was supported by the European Union contracts N ERBBIO4CT960699 and QLG3-

CT-2002-00826, by the Swedish Medical Research Council, the Cancer Research Fund of Sweden, the Lars Hierta Foundation, the Göran Gustafsson Foundation, the Novo Nordisk Foundation, the Academy of Finland and the Sigrid Jusélius Foundation.

Send reprint requests to: Dr. Jyrki Kukkonen, Department of Neuroscience, Physiology, Uppsala University, BMC, P.O. Box 572, SE-75123 Uppsala, Sweden. E-mail:

jkukkone@fysiologi.uu.se 
JPET/2002/48025

\section{TABLE 1}

Alanine-scanned C-terminal Orexin-A-peptides

The replaced amino acid is shown in bold underlined.

\begin{tabular}{|c|c|}
\hline $\begin{array}{l}\text { Position of } \\
\text { replacement }\end{array}$ & Sequence \\
\hline Orexin- $\mathrm{A}_{14-33}$ & CRLYELLHGAGNHAAGILTL-amide \\
\hline Orexin- $\mathrm{A}_{14-33} \mathrm{C} 14 \mathrm{~A}$ & $\underline{A}$ RLYELLHGAGNHAAGILTL-amide \\
\hline Orexin- $A_{14-33} R 15 A$ & CALYYELLHGAGNHAAGILTL-amide \\
\hline Orexin- $\mathrm{A}_{14-33} \mathrm{~L} 16 \mathrm{~A}$ & CRAYELLHGAGNHAAGILTL-amide \\
\hline Orexin- $\mathrm{A}_{14-33} \mathrm{Y} 17 \mathrm{~A}$ & CRLÄELLHGAGNHAAGILTL-amide \\
\hline Orexin- $\mathrm{A}_{14-33} \mathrm{~F} 18 \mathrm{~A}$ & CRLYALLLHGAGNHAAGILTL-amide \\
\hline Orexin- $\mathrm{A}_{14-33} \mathrm{~L} 19 \mathrm{~A}$ & CRLYEALLHGAGNHAAGILTL-amide \\
\hline Orexin- $\mathrm{A}_{14-33} \mathrm{~L} 20 \mathrm{~A}$ & CRLYELAHGAGNHAAGILTL-amide \\
\hline Orexin- $\mathrm{A}_{14-33} \mathrm{H} 21 \mathrm{~A}$ & CRLYELLAGAGNHAAGILTL-amide \\
\hline Orexin- $\mathrm{A}_{14-33} \mathrm{G} 22 \mathrm{~A}$ & CRLYELLHAAGNHAAGILTL-amide \\
\hline Orexin- $\mathrm{A}_{14-33} \mathrm{G} 24 \mathrm{~A}$ & CRLYELLHGAANHAAGILTL-amide \\
\hline Orexin- $\mathrm{A}_{14-33} \mathrm{~N} 25 \mathrm{~A}$ & CRLYELLHGAGAHAAGILTL-amide \\
\hline Orexin- $\mathrm{A}_{14-33} \mathrm{H} 26 \mathrm{~A}$ & CRLYELLHGAGNAAAGILTL-amide \\
\hline
\end{tabular}




\section{JPET/2002/48025}

\section{TABLE 2}

$\mathrm{Ca}^{++}$responses of $\mathrm{OX}_{1}$ and $\mathrm{OX}_{2}$ receptors to orexin- $\mathrm{A}$ and orexin-B in normal and low extracellular $\mathrm{Ca}^{++}$

$N=8$.

\begin{tabular}{|c|c|c|c|c|c|c|c|}
\hline & \multicolumn{3}{|c|}{$1 \mathrm{mM}\left[\mathrm{Ca}^{++}\right]_{\mathrm{e}}$} & \multicolumn{3}{|c|}{$140 \mathrm{nM}\left[\mathrm{Ca}^{++}\right]_{\mathrm{e}}$} \\
\hline & & $\operatorname{Max}(\mathrm{nM})$ & $\mathrm{pEC}_{50}$ & $\mathrm{n}_{\text {Hill }}$ & $\operatorname{Max}(\mathrm{nM})$ & $\mathrm{pEC}_{50}(\mathrm{M})$ & $\mathrm{n}_{\text {Hill }}$ \\
\hline \multirow[t]{2}{*}{$\mathrm{OX}_{1}$} & Orexin-A & $1257 \pm 99$ & $8.43 \pm 0.05$ & 1.7 & $1346 \pm 141$ & $7.28 \pm 0.08$ & 2.5 \\
\hline & Orexin-B & $1245 \pm 132$ & $7.59 \pm 0.11$ & 1.9 & $1212 \pm 134$ & $6.78 \pm 0.09$ & 2.2 \\
\hline \multirow[t]{2}{*}{$\mathrm{OX}_{2}$} & Orexin-A & $999 \pm 193$ & $8.17 \pm 0.07$ & 1.4 & $1080 \pm 291$ & $7.16 \pm 0.07$ & 2.1 \\
\hline & Orexin-B & $767 \pm 201$ & $8.16 \pm 0.10$ & 1.8 & $835 \pm 194$ & $7.37 \pm 0.06$ & 3.6 \\
\hline
\end{tabular}




\section{JPET/2002/48025}

\section{TABLE 3}

Normalized $\mathrm{Ca}^{++}$responses of $\mathrm{OX}_{1}$ and $\mathrm{OX}_{2}$ receptors to orexin-A and orexin-B in normal and low extracellular $\mathrm{Ca}^{++}$

The data from the same experiments as in table 3 were normalized to the response to orexin- $\mathrm{A}$ in $1 \mathrm{mM}\left[\mathrm{Ca}^{++}\right]_{\mathrm{e}}$ in each batch of cells.

\begin{tabular}{|c|c|c|c|c|c|}
\hline & \multicolumn{2}{|c|}{$1 \mathrm{mM}\left[\mathrm{Ca}^{++}\right]_{\mathrm{e}}$} & \multicolumn{2}{|c|}{$140 \mathrm{nM}\left[\mathrm{Ca}^{++}\right]_{\mathrm{e}}$} \\
\hline & & $\operatorname{Max}(\times$ ctrl $)$ & $\mathrm{EC}_{50}(\times \mathrm{ctrl})$ & $\operatorname{Max}(\times \operatorname{ctrl})$ & $\mathrm{EC}_{50}(\times \mathrm{ctrl})$ \\
\hline \multirow[t]{2}{*}{$\mathrm{OX}_{1}$} & Orexin-A & $1.0 \pm 0.1$ & $1.0 \pm 0.1$ & $1.1 \pm 0.1$ & $14 \pm 3^{a}$ \\
\hline & Orexin-B & $0.90 \pm 0.04$ & $6.9 \pm 1.8^{a}$ & $0.87 \pm 0.06^{c}$ & $46 \pm 9^{b e}$ \\
\hline \multirow[t]{2}{*}{$\mathrm{OX}_{2}$} & Orexin-A & $1.0 \pm 0.1$ & $1.0 \pm 0.2$ & $1.1 \pm 0.1^{a}$ & $10 \pm 2^{a}$ \\
\hline & Orexin-B & $0.76 \pm 0.03^{a}$ & $1.0 \pm 0.2$ & $0.80 \pm 0.07^{d}$ & $6.3 \pm 0.9^{b c}$ \\
\hline
\end{tabular}

${ }^{a}$ Significantly different $(\mathrm{p}<0.001)$ as compared to orexin-A in $1 \mathrm{mM}\left[\mathrm{Ca}^{++}\right]_{\mathrm{e}}$

${ }^{b}$ Significantly different $(\mathrm{p}<0.001)$ as compared to orexin- $\mathrm{B}$ in $1 \mathrm{mM}\left[\mathrm{Ca}^{++}\right]_{\mathrm{e}}$

${ }^{c}$ Significantly different $(\mathrm{p}<0.05)$ as compared to orexin-A in $140 \mathrm{nM}\left[\mathrm{Ca}^{++}\right]_{\mathrm{e}}$

${ }^{d}$ Significantly different $(\mathrm{p}<0.01)$ as compared to orexin-A in $140 \mathrm{nM}\left[\mathrm{Ca}^{++}\right]_{\mathrm{e}}$

${ }^{e}$ Significantly different $(\mathrm{p}<0.001)$ as compared to orexin-A in $140 \mathrm{nM}\left[\mathrm{Ca}^{++}\right]_{\mathrm{e}}$

All the other reasonable comparisons yielded non-significant. 


\section{JPET/2002/48025}

\section{TABLE 4}

$\mathrm{Ca}^{++}$responses of $\mathrm{CHO}-\mathrm{hOX}_{1}$ to Orexin-A and -B and alanine-scanned orexin-A C-terminal peptides in $1 \mathrm{mM}\left[\mathrm{Ca}^{++}\right]_{\mathrm{e}}$

$N=5-11$

\begin{tabular}{|c|c|c|c|}
\hline & $\begin{array}{c}\text { Max (\% of Orexin-A } \\
\text { response) }\end{array}$ & $\mathrm{pEC}_{50}(\mathrm{M})$ & $\mathrm{n}_{\text {Hill }}$ \\
\hline Orexin-A & $100 \pm 1$ & $8.43 \pm 0.05$ & 1.9 \\
\hline Orexin- $A_{14-33}$ & $95 \pm 4$ & $7.57 \pm 0.02$ & 3.1 \\
\hline Orexin- $\mathrm{A}_{14-33} \mathrm{C} 14 \mathrm{~A}$ & $95 \pm 4$ & $7.42 \pm 0.03$ & 2.1 \\
\hline Orexin- $A_{14-33} R 15 A$ & $95 \pm 3$ & $7.15 \pm 0.03$ & 2.7 \\
\hline Orexin- $A_{14-33} L 16 A$ & $97 \pm 6$ & $7.29 \pm 0.02$ & 2.5 \\
\hline Orexin- $A_{14-33}$ Y17A & $94 \pm 4$ & $7.29 \pm 0.03$ & 2.7 \\
\hline Orexin- $A_{14-33} E 18 A$ & $97 \pm 5$ & $7.51 \pm 0.03$ & 2.8 \\
\hline Orexin- $\mathrm{A}_{14-33} \mathrm{~L} 19 \mathrm{~A}$ & $98 \pm 2$ & $7.24 \pm 0.03$ & 1.9 \\
\hline Orexin- $\mathrm{A}_{14-33} \mathrm{~L} 20 \mathrm{~A}$ & $93 \pm 3$ & $6.03 \pm 0.04$ & 1.2 \\
\hline Orexin- $\mathrm{A}_{14-33} \mathrm{H} 21 \mathrm{~A}$ & $97 \pm 3$ & $7.40 \pm 0.03$ & 2.7 \\
\hline Orexin- $\mathrm{A}_{14-33} \mathrm{G} 22 \mathrm{~A}$ & $94 \pm 4$ & $7.35 \pm 0.03$ & 2.6 \\
\hline Orexin- $\mathrm{A}_{14-33} \mathrm{G} 24 \mathrm{~A}$ & $97 \pm 5$ & $7.47 \pm 0.02$ & 2.6 \\
\hline Orexin- $A_{14-33} \mathrm{~N} 25 \mathrm{~A}$ & $100 \pm 5$ & $7.04 \pm 0.05$ & 1.8 \\
\hline Orexin- $\mathrm{A}_{14-33} \mathrm{H} 26 \mathrm{~A}$ & $95 \pm 4$ & $6.77 \pm 0.05$ & 1.3 \\
\hline
\end{tabular}




\section{JPET/2002/48025}

\section{TABLE 5}

$\mathrm{Ca}^{++}$responses of $\mathrm{CHO}-\mathrm{hOX}_{2}$ to Orexin-A and -B and alanine-scanned orexin-A C-terminal peptides in $1 \mathrm{mM}\left[\mathrm{Ca}^{++}\right]_{\mathrm{e}}$

$N=8-15$.

\begin{tabular}{|c|c|c|c|}
\hline & $\begin{array}{c}\text { Max (\% of Orexin-A } \\
\text { response) }\end{array}$ & $\mathrm{pEC}_{50}(\mathrm{M})$ & $\mathrm{n}_{\text {Hill }}$ \\
\hline Orexin-A & $100 \pm 1$ & $8.17 \pm 0.07$ & 1.6 \\
\hline Orexin- $A_{14-33}$ & $103 \pm 5$ & $7.57 \pm 0.03$ & 3.7 \\
\hline Orexin- $\mathrm{A}_{14-33} \mathrm{C} 14 \mathrm{~A}$ & $99 \pm 4$ & $7.43 \pm 0.03$ & 3.2 \\
\hline Orexin- $A_{14-33} R 15 A$ & $95 \pm 4$ & $7.07 \pm 0.03$ & 1.6 \\
\hline Orexin- $A_{14-33} \mathrm{~L} 16 \mathrm{~A}$ & $95 \pm 4$ & $7.32 \pm 0.03$ & 1.5 \\
\hline Orexin- $\mathrm{A}_{14-33} \mathrm{Y} 17 \mathrm{~A}$ & $106 \pm 3$ & $7.09 \pm 0.04$ & 2.1 \\
\hline Orexin- $A_{14-33} E 18 A$ & $98 \pm 1$ & $7.55 \pm 0.06$ & 3.1 \\
\hline Orexin- $\mathrm{A}_{14-33} \mathrm{~L} 19 \mathrm{~A}$ & $98 \pm 5$ & $7.40 \pm 0.03$ & 3.0 \\
\hline Orexin- $A_{14-33} L 20 A$ & $99 \pm 0.4$ & $6.38 \pm 0.03$ & 1.6 \\
\hline Orexin- $\mathrm{A}_{14-33} \mathrm{H} 21 \mathrm{~A}$ & $97 \pm 2$ & $7.44 \pm 0.02$ & 2.8 \\
\hline Orexin- $A_{14-33} G 22 A$ & $100 \pm 3$ & $7.33 \pm 0.02$ & 2.9 \\
\hline Orexin- $A_{14-33} G 24 A$ & $95 \pm 4$ & $7.54 \pm 0.02$ & 3.5 \\
\hline Orexin- $\mathrm{A}_{14-33} \mathrm{~N} 25 \mathrm{~A}$ & $96 \pm 5$ & $7.31 \pm 0.02$ & 3.4 \\
\hline Orexin- $\mathrm{A}_{14-33} \mathrm{H} 26 \mathrm{~A}$ & $104 \pm 2$ & $7.20 \pm 0.02$ & 2.1 \\
\hline
\end{tabular}


JPET/2002/48025

\section{Legends for figures}

Fig. 1. Orexin-A and -B peptide sequences. The gray boxes mark the identical amino acids. The numbering of the amino acids is for orexin-A. Q* indicates the N-terminal pyroglutamoyl residue.

Fig. 2. Concentration-response curves for orexin- $\mathrm{A}$ and $-\mathrm{B}$ on $\mathrm{OX}_{1}(\mathrm{~A})$ and $\mathrm{OX}_{2}(\mathrm{~B})$ receptors in normal $(1 \mathrm{mM})$ and low $(140 \mathrm{nM})\left[\mathrm{Ca}^{++}\right]_{\mathrm{e}} \cdot N=8$. The fitted maximum response of each curve is normalized to the maximum response to orexin- $\mathrm{A}$ in $1 \mathrm{mM}\left[\mathrm{Ca}^{++}\right]_{\mathrm{e}}$.

Fig. 3. $\mathrm{Ca}^{++}$responses to different concentrations of truncated orexin-A peptides in $1 \mathrm{mM}$ $\left[\mathrm{Ca}^{++}\right]_{\mathrm{e}}$. Please observe the logarithmic ordinate. $N=3$.

Fig. 4. Graphic representation of the $\mathrm{pEC}_{50}$ values determined for alanine-scanned orexin- $\mathrm{A}_{14-33}$ peptides in $1 \mathrm{mM}\left[\mathrm{Ca}^{++}\right]_{\mathrm{e}}$. The data are the same as presented in Tables 4 and 5.

Fig. 5. Concentration-response curves for three different mutated orexin- $A_{14-33}$ peptides in $1 \mathrm{mM}$ $\left[\mathrm{Ca}^{++}\right]_{\mathrm{e}}$. In A, Leu20 to Ala mutation shifts the concentration response curve of orexin- $\mathrm{A}_{14-33} 15-$ 35-fold to the right. In, B His21Ala mutation results in peptides with apparent highly cooperative response (steep concentration-response curves). Leu20Ala (A) and His26Ala (C) mutations show that the $\mathrm{OX}_{1}$ receptor is more sensitive to the orexin-A mutations than the $\mathrm{OX}_{2}$ receptor. $N=9$. 


\section{JPET/2002/48025}

Fig. 6. Comparison of the $\mathrm{pEC}_{50}$ values of selected orexin- $\mathrm{A}_{14-33}$ peptides in normal $(1 \mathrm{mM})$ and low $(140 \mathrm{nM})\left[\mathrm{Ca}^{++}\right]_{\mathrm{e}}$. Please observe that the $\mathrm{pEC}_{50}$ of Leu20Ala peptide could not be determined in $140 \mathrm{nM}\left[\mathrm{Ca}^{2+}\right]_{\mathrm{e}}$ because of its low potency. 
Orexin- $\mathrm{A}_{1-33}$

Orexin- $B_{1-28}$

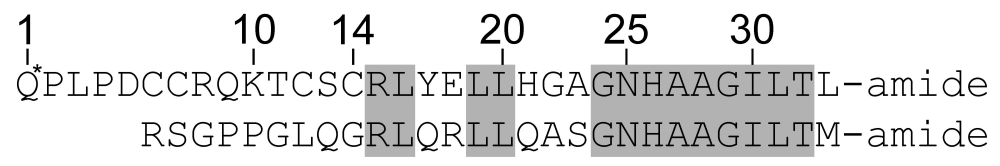




\section{Fig. 4}

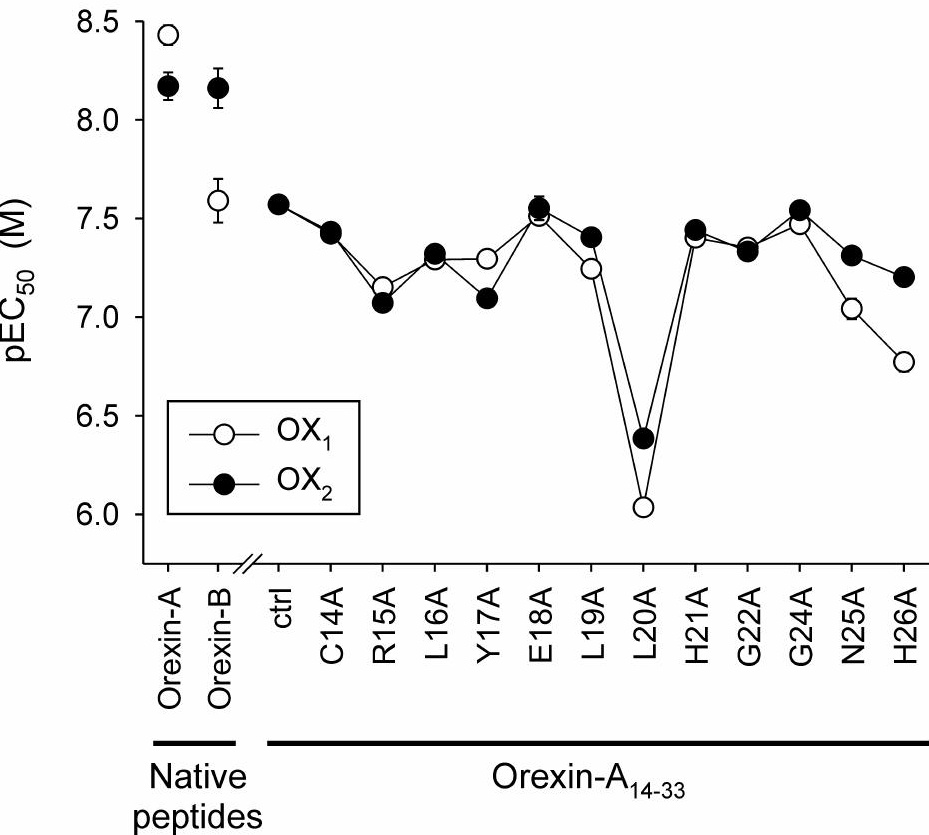



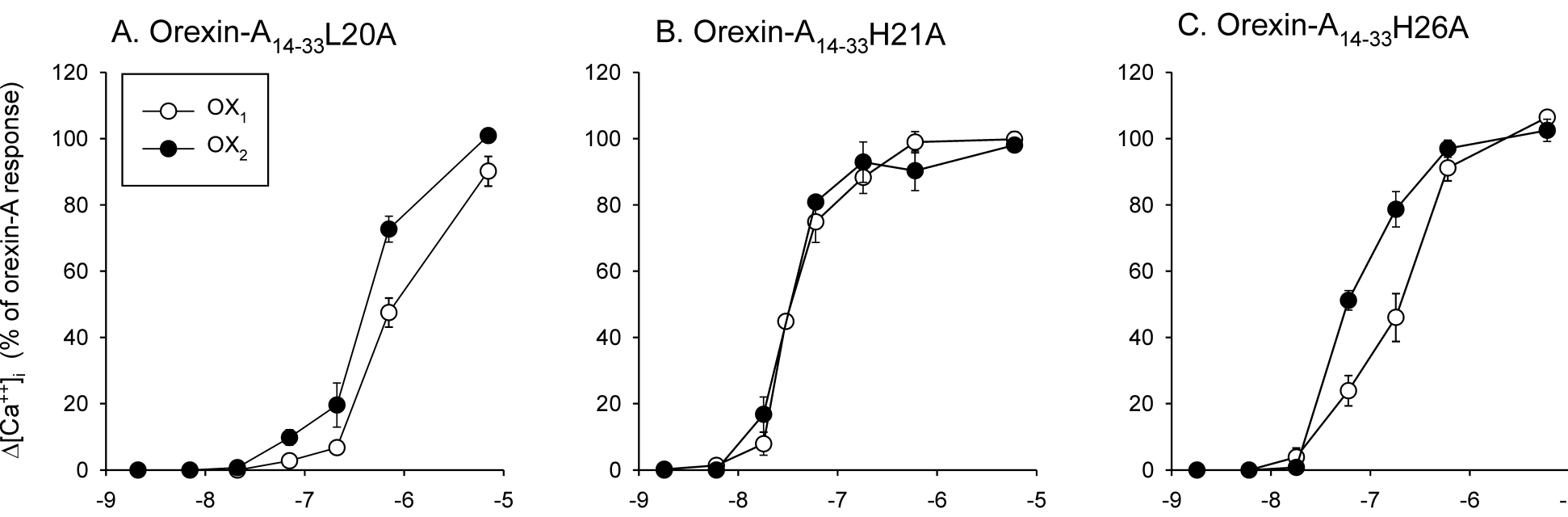

log[peptide] (M) 

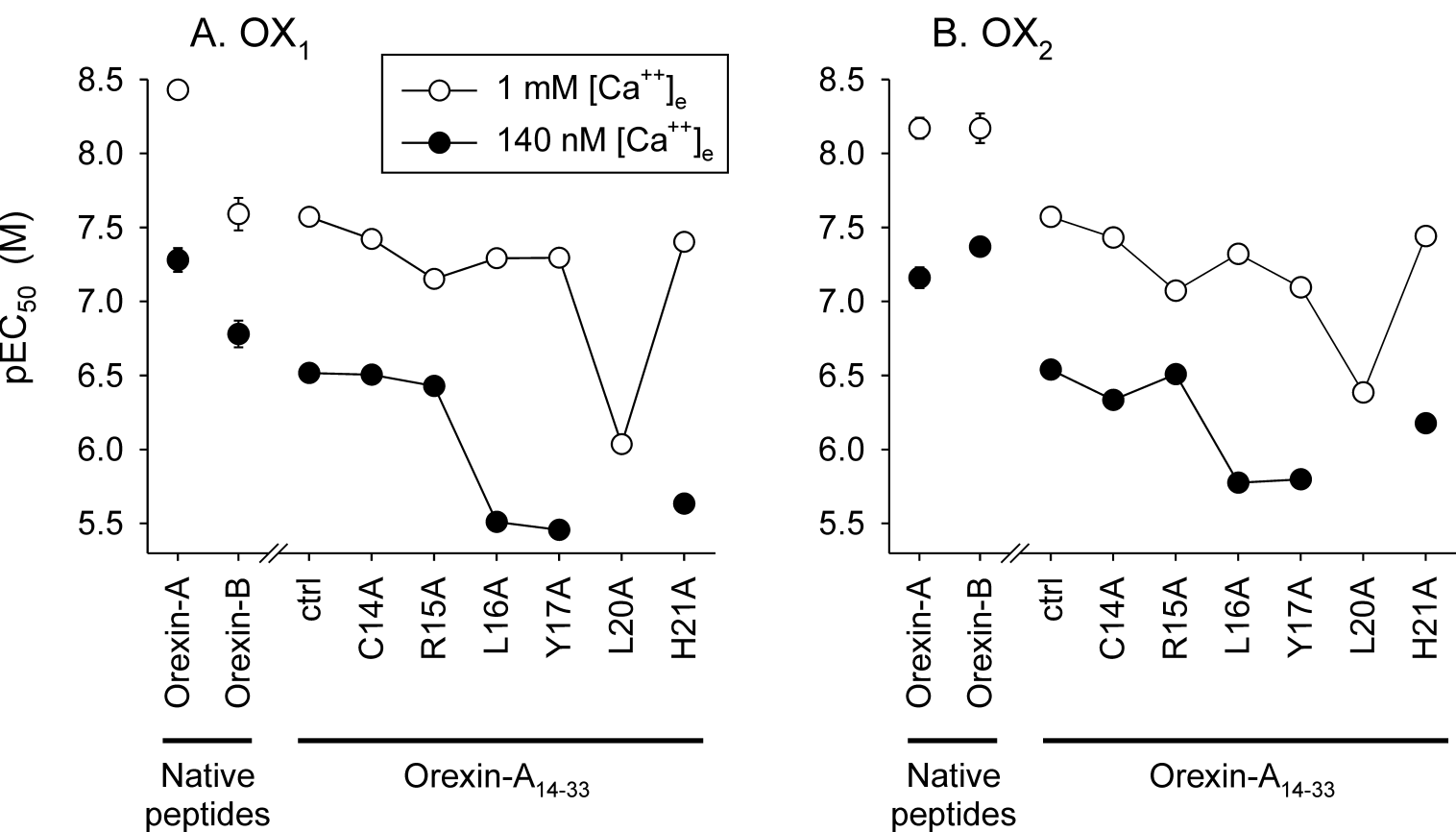